\title{
Effects of aviation kerosene contents on the environment and method of its cleansing
}

\author{
Yusuf Isokov*, Normaxmat Yodgorov, Sadulla Sultonov, and Sanjar Khalilov \\ Institute of General and Inorganic chemistry, Academy of sciences of Republic of Uzbekistan, \\ Tashkent, Uzbekistan
}

\begin{abstract}
The high content of sulfur compounds in aviation kerosene produced at the Bukhara Oil Refinery (BOR) is causing great damage to the environment. Purification of sulfur compounds in aviation kerosene using activated charcoal is effective. One way to remove sulfur compounds from aviation kerosene is to clean them using activated charcoal (adsorbent) obtained based on fruit pods.

Purification of aviation kerosene from mercaptans is a chemical adsorption process, using activated charcoal obtained based on shells of fruit seeds (walnuts, peaches, apricots, etc.). The adsorption of activated carbon obtained on the basis of husks of fruit seeds (walnuts, peaches, apricots, etc.) depends on the physicochemical properties; such activated charcoals were obtained by thermochemical methods.
\end{abstract}

\section{Introduction}

Preventing biological imbalances on the planet is the biggest challenge. The development of industry, the use of natural resources in various ways are causing great damage to nature and the environment. The issue of nature protection, its efficient and proper use, primarily based on environmental laws, is one of the main tasks of human society $[1,16]$. One of the most important issues facing the world community today is to ensure human security globally, particularly environmental security, and a lot of research is being done in this direction. Due to the high content of sulfur compounds in jet fuel, sulfur also burns when jet fuel burns and releases large amounts of sulfur (IV) oxide into the environment.

$$
\mathrm{S}+\mathrm{O}_{2}=\mathrm{SO}_{2}
$$

Due to the high content of sulfur oxides in the air, when it rains, sulfur (IV) oxide reacts with water to form acid rain.

$$
\mathrm{SO}_{2}+\mathrm{H}_{2} \mathrm{O}=\mathrm{H}_{2} \mathrm{SO}_{3}
$$

Republican production can prevent pollution of water bodies in cities due to the fact that the plant reacts with $\mathrm{Ca}^{+2}, \mathrm{Na}^{+}, \mathrm{K}^{+}, \mathrm{Mg}^{+2}$, etc., in the water by adding to the saline water

*Corresponding author: yxoriddinovich2001@mail.ru 
accumulated in the water basins of factories. The amount of salt in the water is increasing. It was found that these salts were reduced from $25 \mathrm{eq} / \mathrm{g}$ hardness to $4 \mathrm{mg}$-eqv/l when purified with activated charcoal derived from local raw materials. It was reduced from 25 $\mathrm{mg}-\mathrm{eq} / \mathrm{l}$ to $6 \mathrm{eq} / \mathrm{g}$ when cleaned with imported ACTICARBON brand coal.

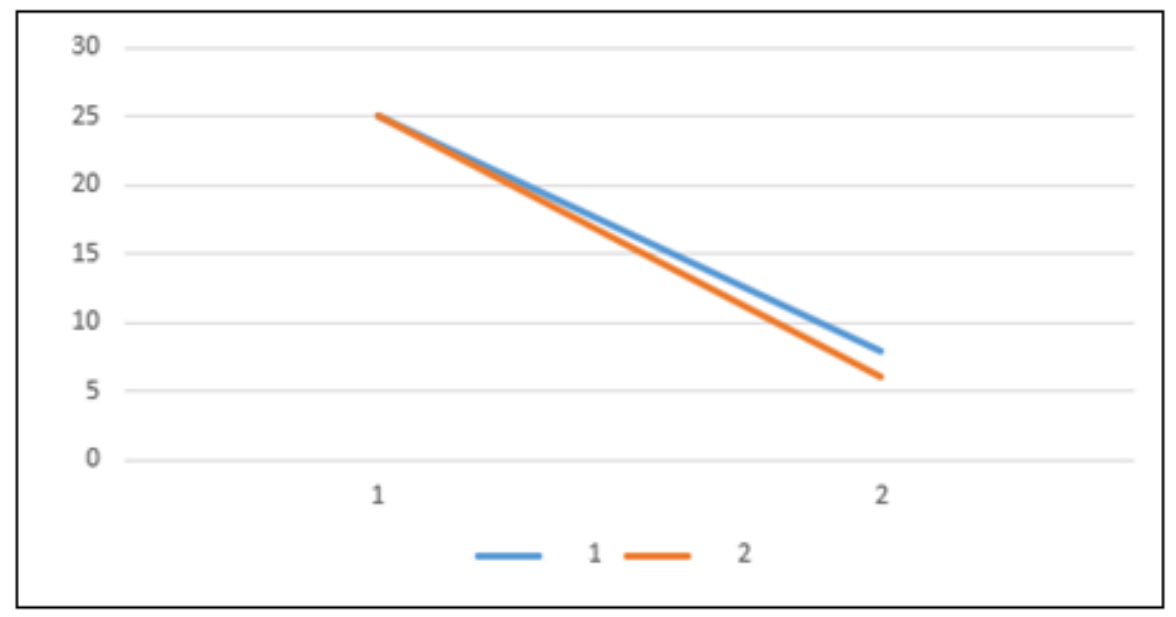

Fig 1. Level of wastewater treatment using activated carbon

Major pollutants are industrial enterprises, boilers and furnaces of thermal power plants. They are also car engines. Many substances in industry and agriculture (biological cycle of substances) are not processed. All components of the biosphere, primarily atmospheric air, are polluted.

One third of the pollutants released into the atmosphere are carbon monoxide. It comes mainly from exhaust fumes from cars, power plants and industrial plants. Every year, 250 million tons of carbon monoxide. As a result of research, the purification of sulfur compounds in jet fuel is a topical issue. Currently, more coal and other solid combustible minerals are being used to synthesize such materials.

Due to the abundance of techniques, the lack of high-quality activated carbon with high adsorption properties in various industries is one of the current problems. Areas of use of activated carbon are covered. $[2,15]$ According to him, the main areas of application of carbon adsorbents are food $-42 \%$, technological processes - $38 \%$, environmental protection - $10 \%$. In the analysis of the literature $[3,15]$, it can be seen that it is also used to refining petroleum products, in the extraction of gold, and in several other precious metals. In addition, scientific research is being conducted on producing and using activated carbon for environmental protection $[4,6,13]$.

In addition to the industries listed above, activated carbon is currently also used to manufacture supercapacitors and batteries. The quality indicators used in supercapacitors and batteries are characterized by high technical characteristics $[5,16]$.

Activated carbon adsorbents are mainly used in various technological processes to purify basic products from additives in the form of gaseous and liquid aggregates. For example, activated charcoal plays an important role in the synthesis of drugs, especially antibiotics. activated carbon adsorbents are used in the final stages of obtaining drugs in the purification processes of adsorbents converted into tablets and other forms [5, 15]. 


\section{Methods}

Car engines emit carbon monoxide and carcinogens, carbon monoxide, nitrogen oxides, aldehydes, hydrocarbons, and acids into the atmosphere. In the United States, one car emits the following amounts of pollutants into the atmosphere per year: $800 \mathrm{~kg}$ of carbon monoxide, $115 \mathrm{~kg}$ of hydrocarbons, $38 \mathrm{~kg}$ of nitrogen oxides. The accumulation of carbon monoxide, especially in large cities, can have negative consequences. In general, its accumulation in the biosphere is not observed because plants and soil microorganisms absorb most of it. [1].

As the main raw material was selected, waste from walnuts, peaches, and the resulting adsorbent FK-YOK-136, FK-SHK was named as follows. This fruit was pyrolyzed at a high temperature of $400-4500 \mathrm{C}$ in an airtight place at a high temperature and thermochemically activated.

Various physicochemical methods were used to study the samples obtained. In particular, the mechanical strength of the granules was determined on an IPG-1 device and viewed under an electroscope.

The specific surface area of the granules is determined by the adsorption method "Sorbi N.1.1." in the equipment, while the total volume of the pores was determined from the water absorption of the granules.

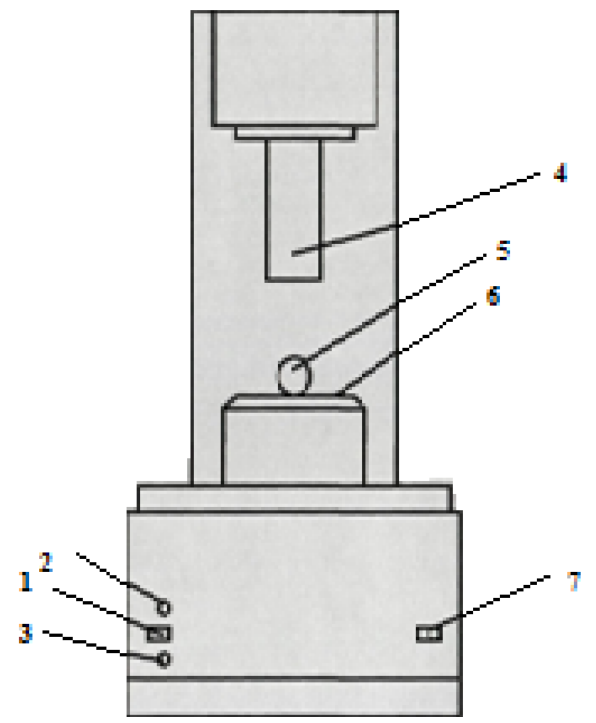

Fig 2. Scheme for determining the mechanical strength of the granule. 1 is control button; 2 is pusk; 3 is burners; 4 is stock; 5 is sample; 6 is basis; 7 is alarm lamp.

\section{Results and Discussion}

The obtained activated carbon was used in the purification of aviation kerosene produced at OOO BORefinery. The amount of mercaptan following the requirements of GOST ASTMD 3227 in the vibrating device METTLERDL25 was determined to be $0.013 \%$. Mercaptan was purified in the laboratory with activated charcoal obtained based on $0.013 \%$ aviakerosene based on fruit seeds. Factory demand KSt 16472899-007: 2012 should be equal to $0.003 \%$.

The use of activated carbon in the purification of aviation kerosene; 3 diletilnium funnels were obtained, coal samples of the same volume were taken from $800 \mathrm{ml}$, and 0.5 
liters of $1.4 \%$ solution of diethanolamine was passed over these coal samples. To saturate the activated carbon sample, $2.25 \mathrm{~g}$ of ARI-100 catalyst was passed, and the activated carbon samples were saturated in the same amount. The saturation of the activated carbon sample was seen in the color of the catalyst, turned light blue, activated carbon was ready for use.

0.5 liters of aviation kerosene was weighed, and a $6.6 \% 0.1$ liter solution of $\mathrm{NaOH}$ was prepared in a 5: 1 ratio and added to aviation kerosene and stirred for 30 minutes, during which the sulfur $\mathrm{NaOH}$ in aviation kerosene was completely reacted.

The prepared solution was passed through 1 drop per second of activated carbon adsorbents, and the results were analyzed in mercaptan following the requirements of GOST ASTMD 3227 in a titration device METTLERDL25 per $100 \mathrm{ml}$ and are given in the table below.

Table 1. Table of saturation of activated carbon with sulfur compounds.

\begin{tabular}{|c|c|c|c|c|c|}
\hline \multirow{2}{*}{$\begin{array}{c}\text { Number } \\
\text { of } \\
\text { transfers } \\
\text { of } 200 \mathrm{ml} \\
\text { paraffin }\end{array}$} & \multirow[t]{2}{*}{$\begin{array}{l}\text { Pre-cleaning } \\
\text { paraffin } \\
\text { analysis, } \%\end{array}$} & \multicolumn{3}{|c|}{ Activated carbon brands } & \multirow[t]{2}{*}{ GOST } \\
\hline & & $\begin{array}{l}\text { ACTICAR } \\
\text { BON }\end{array}$ & $\begin{array}{c}\text { FK-YoK- } \\
136\end{array}$ & FK-ShK & \\
\hline & 0.01 & 0.004 & 0.006 & 0.007 & ASTMD 3227 \\
\hline 2 & 0.01 & 0.004 & 0.004 & 0.007 & ASTMD 3227 \\
\hline 3 & 0.01 & 0.005 & 0.006 & 0.009 & ASTMD 3227 \\
\hline 4 & 0.01 & 0.006 & 0.004 & 0.009 & ASTMD 3227 \\
\hline 5 & 0.01 & 0.006 & 0.005 & 0.008 & ASTMD 3227 \\
\hline
\end{tabular}

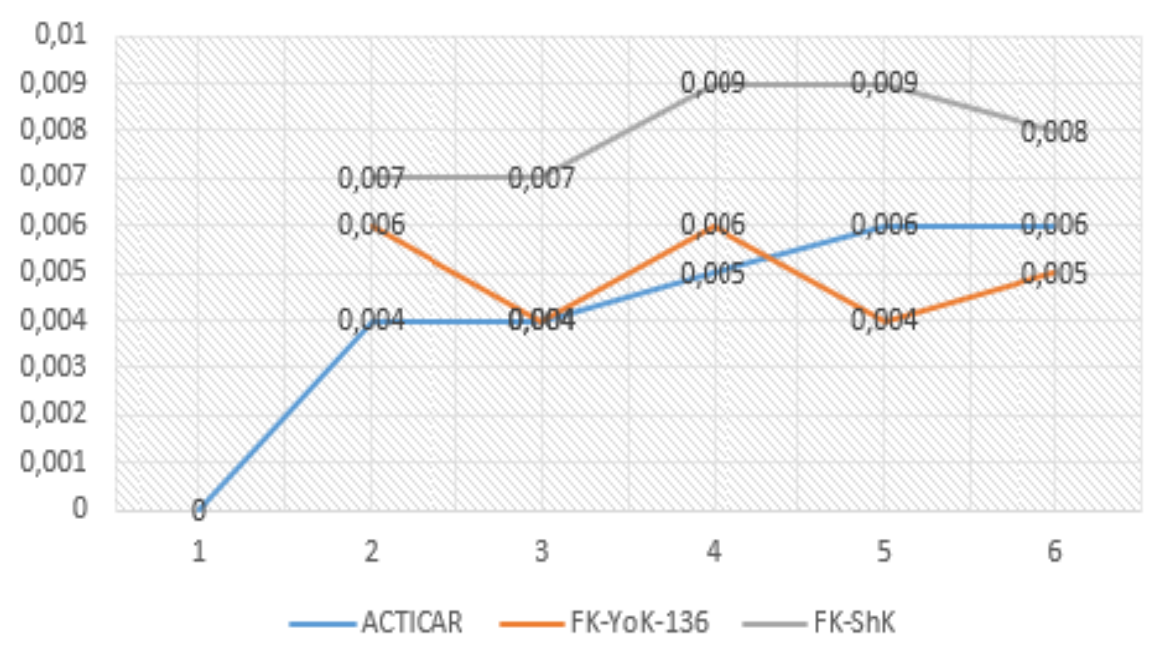

Fig. 3. Saturation diagram during activated carbon aviation kerosene purification

From the above results, it can be seen that the activated carbon samples obtained work better than ACTICARBON.

It was studied that activated carbon's physical and mechanical properties also depend on the method of its preparation. Samples were prepared in three different ways: 
Table 2. The total amount of mercaptan before and after cleaning the jet fuel

\begin{tabular}{|c|c|c|c|c|}
\hline \multirow[b]{2}{*}{$\begin{array}{l}\text { Activation } \\
\text { branded coal }\end{array}$} & \multicolumn{3}{|c|}{ The amount of $\mathrm{C}$ in kerosene, $\%$} & \multirow[b]{2}{*}{ GOST } \\
\hline & $\begin{array}{l}\text { Paraffin } \\
\text { analysis } \\
\text { before } \\
\text { cleaning }\end{array}$ & $\begin{array}{c}\text { Paraffin } \\
\text { analysis } \\
\text { after } \\
\text { cleaning }\end{array}$ & $\begin{array}{c}\text { Paraffin } \\
\text { analysis after } \\
\text { cleaning. } \\
\text { Differences } \\
\text { after cleaning }\end{array}$ & \\
\hline ACTICAR BONE & 0.01 & 0.005 & 0.005 & ASTMD 3227 \\
\hline FK-YoK-136 & 0.01 & 0.005 & 0.005 & ASTMD 3227 \\
\hline FK-SHK & 0.01 & 0.008 & 0.002 & ASTMD 3227 \\
\hline
\end{tabular}

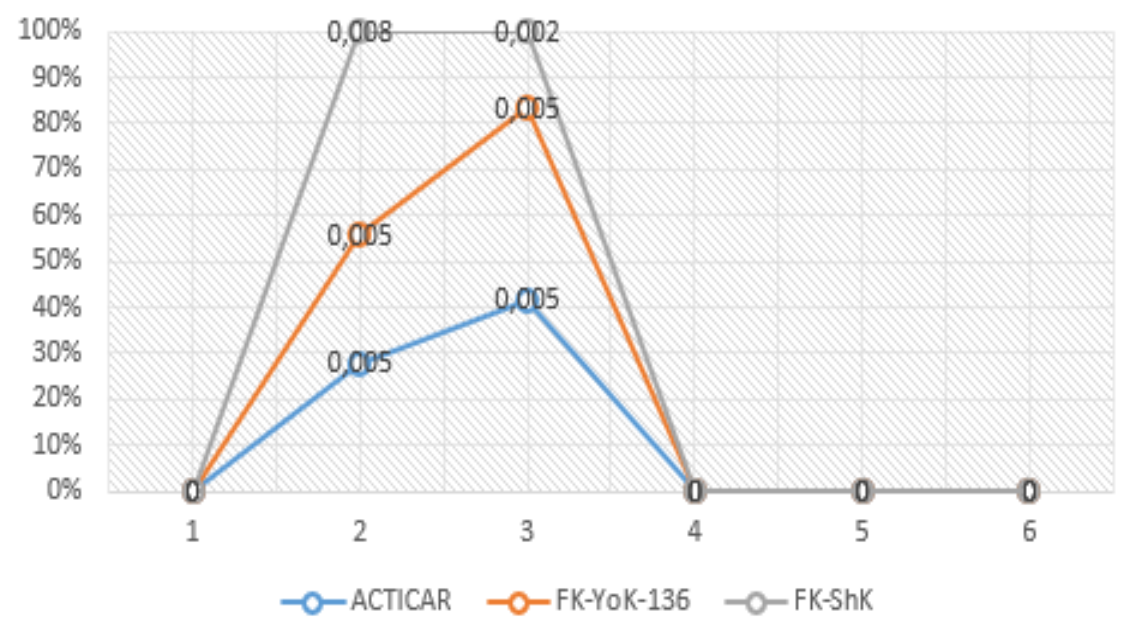

Fig.4. It can be seen that the FK-YOK-136 marl activated carbon worked the same as the imported ACTICARBONE.

\section{Conclusions}

The results of the study showed that it was purified based on the activated carbon we obtained. ACTICARBONE brand coal from America did the same adsorption. The ACTICARBONE brand activated carbon worked the same because the density was small. When local activated carbon was installed in motor vehicles by making a filter from activated carbon, it greatly reduced the release of $\mathrm{SO} 2, \mathrm{SO}, \mathrm{SO} 2, \mathrm{SO} 3$ gases into the environment. When we measured the coal samples in volume units, we were convinced that they work better than ACTICARBONE coal. Thermochemically activated carbon adsorbs better than ordinary water vapor activated carbon.

\section{References}

1. Bansal R.C. Activated carbon adsorption, Taylor and Francis Group, p. 520. USA, (2005).

2. Khaletskiy A.V. Sorbtsiya krasyashchikh veshchestv iz rastvorov pektina aktivirovannym uglem, Voronezhskiy gosudarstvennyy agrarnyy universitet imeni K.D.Glinki, Voronezh. T. 9. Vyp. (2). (2009) 
3. Beletskaya M.G. Sintez uglerodnykh adsorbentov metodom termokhimicheskoy aktivatsii gidroliznogo lignina s ispol'zovaniyem gidroksida natriya, Arkhangel'sk. p. 153. (2014)

4. Kinle KH. Aktivnyye ugli i ikh promyshlennoye primeneniye, p. 215, L.: Khimiya. Leningradskoye otdeleniye, (1984)

5. Mukhin V.M. Proizvodstvo i primeneniye uglerodnykh adsorbentov, Rossiyskiy khimiko-tekhnologicheskiy universitet im. M.V.Mendeleyeva, p. 308, (2012)

6. Budnitskiy G.A. Uglerodnyye volokna i materialy na osnove viskoznykh volokoy. Khimicheskiye volokna, 5, pp. 19- 22. (1993)

7. Khaletskiy A.V. Sorbtsiya krasyashchikh veshchestv iz rastvorov pektina aktivirovannym uglem, Voronezhskiy gosudarstvennyy agrarnyy universitet imeni K.D.Glinki, Voronezh, 9, Vyp. (2), (2009)

8. Patent №2540121 Sposob ochistki legkogo uglevodorodnogo syr'ya ot karbonilsul'fida.

9. Small D.A., Moore N.F. Measurement of Surface Charge of Baculovirus Polyhedra, Appl. Environ. Microbiol., 53(3), pp.598-602, (1987)

10. Van der Mei H.C., Busscher H.J. Electrophoretic Mobility Distributions of SingleStrain Microbial Populations, Appl. Environ. Microbiol., 67(2), pp.491-494, (2001)

11. Okuda S., Igarashi R., Kusui Y., Kasahara Y. Morisaki H. Electrophoretic Mobility of Bacillus subtilis Knockout Mutants with and without Flagella, J. Bacteriol., 185(13), pp. 3711-3717. 2003

12. Coller B.S. The Effects of Ristocetin and von Willebrand Factor on Platelet Electrophoretic Mobility, J. Clin. Invest., 61(5), pp.1168-1175, (1978)

13. Frost M.R., Jackson S.W. Stevens P.J. Adsorption of bacteria onto activated charcoal cloth: An effect of potential importance in the treatment of infected wounds, Microbios. Lett., 13, pp. 135-140, (1980)

14. George N., Davies J.T. Adsorption of Microorganisms on Activated Charcoal Cloth: A Material with Potential Applications in Biotechnology, J. Chem. Tech. Biotechnol., 43, pp. 117-129, (1988)

15. Clark W.B., Bamman L.L., Gibbons R.J. Comparative estimates of bacterial affinities and adsorption sites on hydroxyapatite surfaces, Infect. Immun. (19), № 3, pp. 846853, (1978)

16. Kinle X., Bader E. Aktivnyye ugli i ikh promyshlennoye primeneniye, p.216. Leningrad, Khimiya, (1987) 